\title{
Karyotype Analysis of the Fiddleneck (Phacelia tanacetifolia Benth.)
}

\author{
Ugur Ozkan and Berk Benlioglu \\ Department of Fields Crops, Faculty of Agriculture, Ankara University, Diskapi 06110, Ankara, Turkey
}

\begin{abstract}
Two varieties of fiddleneck (Phacelia tanacetifolia Benth.) plant were determined for visualizing somatic chromosomes. The 4-5 days old root tips were pre-treated in $6 \% \alpha$-monobromonaphtalane in $+4{ }^{\circ} \mathrm{C}$ for $7.5 \mathrm{~h}$, then fixed in glacial acetic acid for 30 min and transferred to $70 \%$ ethanol for long storage. When the root tips were analyzed, they were hydrolyzed with $1 \mathrm{~N} \mathrm{HCl} \mathrm{for} 13$ min at room temperature $\left(25^{\circ} \mathrm{C}\right)$. After hydrolyzing, root tips were stained with $2 \%$ aceto orcein in darkness for $2.5 \mathrm{~h}$. The squash method for preparation was used for chromosomal investigations. The chromosome length (C), relative length (RL), the long arm (L) and short arm (S) lengths, arm ratio (AR; L/S) and centromeric index (S/C) were calculated for caryologic parameters. The ideograms and detailed chromosome morphology measurements of the species were performed by the use of MicroMeasure 3.3. According to results, fiddleneck (Phacelia tanacetifolia Benth.) has $2 n=22$ chromosomes and the karyotype formulas of two varieties of fiddleneck were 16 median and 6 submedian $(16 \mathrm{~m}+6 \mathrm{sm})$.
\end{abstract}

Key words: Fiddleneck, cytogenetic, karyotype, micro measure, chromosome number, Phacelia tanacetifolia.

\section{Introduction}

Fiddleneck (Phacelia tanacetifolia Benth.) is a genus of about 200 species of annual or perennial herbaceous plants, which are members of the family Boraginaceae and are native to Southwestern United States and Mexico [1]. Many species can be cultivated as honey plants and garden plants due to its aesthetic appearance. Fiddleneck (Phacelia tanacetifolia Benth.) is an annual plant. Moreover, the genus is one of the top 20 most common bee plants as a rich source of nectar and pollen, most preferred by honey bees [2]. It is particularly an important source of nectar for wild bees, such as Bombus [3]. Since fiddleneck (Phacelia tanacetifolia Benth.) is attractive to a large number of insects, it can be used as a trap plant in the field as a biological preventive against the harms of crop plants [4]. Thus, it can also help the environment by minimizing the application of pesticides [5]. It is also attractive to hoverflies (family Syrphidae), which are useful as biological pest control agents, because they

Corresponding author: Ugur Ozkan, Ph.D. student, research fields: forage crops, pasture and meadow. feed on aphids and other pests [6]. The photodormant seeds of fiddleneck (Phacelia tanacetifolia Benth.) can only germinate in the dark [7].

Two varieties of fiddleneck (Phacelia tanacetifolia Benth.), which is used as materials in this study, is registered officially in Turkey. Also, these varieties are very important for bee forage and beekeeping. In addition, these two varieties of fiddleneck are thought to use as parental plant in breeding programmes. After determining chromosome numbers and caryological features of these varieties, it is planned to intercross with their relatives which have same ploidy level. Although, there has been a lack of cytological information in the relevant literature in regard to the subject of the study-fiddleneck (Phacelia tanacetifolia Benth.) and no caryological studies have been reported. Therefore, the study aimed to determine the number of chromosomes, cytological characteristics and the methods that can be utilized to characterize the genus of fiddleneck (Phacelia tanacetifolia Benth.).

\section{Materials and Methods}

The seeds of fiddleneck (Phacelia tanacetifolia 
Benth.) in the karyotype analysis were obtained from Saglamtimur Aegean Agricultural Research Institute, and the type of Enton was provided by the gene bank.

For visualizing somatic chromosomes, root tips were obtained from germinated fiddleneck (Phacelia tanacetifolia Benth.) seeds germinated in petri dishes at room temperature $\left(25^{\circ} \mathrm{C}\right)$. The $4-5$ days old root tips were pre-treated in $6 \% \alpha$-monobromonaphtalane in $+4{ }^{\circ} \mathrm{C}$ for $7.5 \mathrm{~h}$, then fixed in glacial acetic acid for $30 \mathrm{~min}$ and transferred to $70 \%$ ethanol for long storage. When the root tips were analyzed, they were hydrolyzed with $1 \mathrm{~N} \mathrm{HCl}$ for $13 \mathrm{~min}$ at room temperature $\left(25{ }^{\circ} \mathrm{C}\right)$. After hydrolyzing, root tips stained with $2 \%$ aceto orcein in darkness for $2.5 \mathrm{~h}$. Then, finally they were squashed in $45 \%$ acetic acid. Slides were observed with Olympus BX-51 microscope, photographs were taken with Olympus
BX-51 camera at room temperature $\left(25^{\circ} \mathrm{C}\right)$ and the magnification was $8,000 \times$. Six chromosomal parameters were measured by MicroMeasure 3.3 program [8], i.e., chromosome length (C), relative length (RL), the long arm (L) and short arm (S) lengths, arm ratio (AR; L/S), centromeric index (S/C). Ideograms were drawn based on long arm length/short arm length. Karyotype formulas of two varieties of fiddleneck were determined by the methods in Ref. [9].

\section{Results and Discussion}

In this study, the somatic chromosomes number and cytological features of two varieties of fiddleneck (Phacelia tanacetifolia Benth.) were determined. Table 1 presents the caryological characteristics on the cultivars of Enton and Saglamtimur. The images of two fiddleneck (Phacelia tanacetifolia Benth.) varieties and

Table 1 Caryological features of Enton and Saglamtimur cultivars.

\begin{tabular}{|c|c|c|c|c|c|c|c|}
\hline Number & Type & $\begin{array}{l}\text { Chromosome } \\
\text { length }(\mu \mathrm{m})\end{array}$ & $\begin{array}{l}\text { Relative length } \\
(\%)\end{array}$ & $\begin{array}{l}\text { Long arm lenght } \\
(\mu \mathrm{m})\end{array}$ & $\begin{array}{l}\text { Short arm lenght } \\
(\mu \mathrm{m})\end{array}$ & Arm ratio & $\begin{array}{l}\text { Centromeric } \\
\text { index }\end{array}$ \\
\hline \multicolumn{8}{|c|}{ Enton cultivar } \\
\hline 1 & $\mathrm{~m}$ & 4.73 & 11.42 & 2.80 & 1.93 & 1.45 & 0.81 \\
\hline 2 & $\mathrm{sm}$ & 4.26 & 10.27 & 2.87 & 1.39 & 2.06 & 0.65 \\
\hline 3 & $\mathrm{~m}$ & 4.13 & 9.97 & 2.48 & 1.65 & 1.50 & 0.80 \\
\hline 4 & $\mathrm{~m}$ & 3.97 & 9.59 & 2.36 & 1.62 & 1.46 & 0.81 \\
\hline 5 & $\mathrm{sm}$ & 3.85 & 9.30 & 2.45 & 1.40 & 1.75 & 0.73 \\
\hline 6 & $\mathrm{~m}$ & 3.70 & 8.93 & 1.92 & 1.78 & 1.08 & 0.96 \\
\hline 7 & $\mathrm{~m}$ & 3.56 & 8.59 & 2.20 & 1.36 & 1.62 & 0.76 \\
\hline 8 & $\mathrm{~m}$ & 3.49 & 8.43 & 2.07 & 1.43 & 1.45 & 0.82 \\
\hline 9 & $\mathrm{~m}$ & 3.43 & 8.27 & 1.94 & 1.49 & 1.30 & 0.87 \\
\hline 10 & $\mathrm{sm}$ & 3.36 & 8.12 & 2.27 & 1.10 & 2.50 & 0.64 \\
\hline 11 & $\mathrm{~m}$ & 2.94 & 7.11 & 1.75 & 1.19 & 1.47 & 0.80 \\
\hline Total & & 41.42 & & & & & \\
\hline \multicolumn{8}{|c|}{ Saglamtimur cultivar } \\
\hline 1 & $\mathrm{sm}$ & 5.79 & 13.15 & 3.73 & 2.06 & 1.81 & 0.72 \\
\hline 2 & $\mathrm{sm}$ & 4.81 & 10.92 & 3.08 & 1.73 & 1.78 & 0.72 \\
\hline 3 & $\mathrm{sm}$ & 4.65 & 10.56 & 3.00 & 1.65 & 1.82 & 0.71 \\
\hline 4 & $\mathrm{~m}$ & 4.50 & 10.22 & 2.77 & 1.73 & 1.60 & 0.77 \\
\hline 5 & $\mathrm{~m}$ & 4.29 & 9.75 & 2.59 & 1.71 & 1.51 & 0.80 \\
\hline 6 & $\mathrm{~m}$ & 3.98 & 9.04 & 2.13 & 1.84 & 1.16 & 0.93 \\
\hline 7 & $\mathrm{~m}$ & 3.51 & 7.97 & 2.01 & 1.42 & 1.42 & 0.81 \\
\hline 8 & $\mathrm{~m}$ & 3.37 & 7.66 & 1.99 & 1.39 & 1.43 & 0.82 \\
\hline 9 & $\mathrm{~m}$ & 3.26 & 7.41 & 1.77 & 1.49 & 1.19 & 0.91 \\
\hline 10 & $\mathrm{~m}$ & 3.12 & 7.10 & 1.76 & 1.36 & 1.29 & 0.87 \\
\hline 11 & $\mathrm{~m}$ & 2.74 & 6.23 & 1.85 & 0.89 & 2.08 & 0.65 \\
\hline
\end{tabular}

m: median; sm: sub-median. 


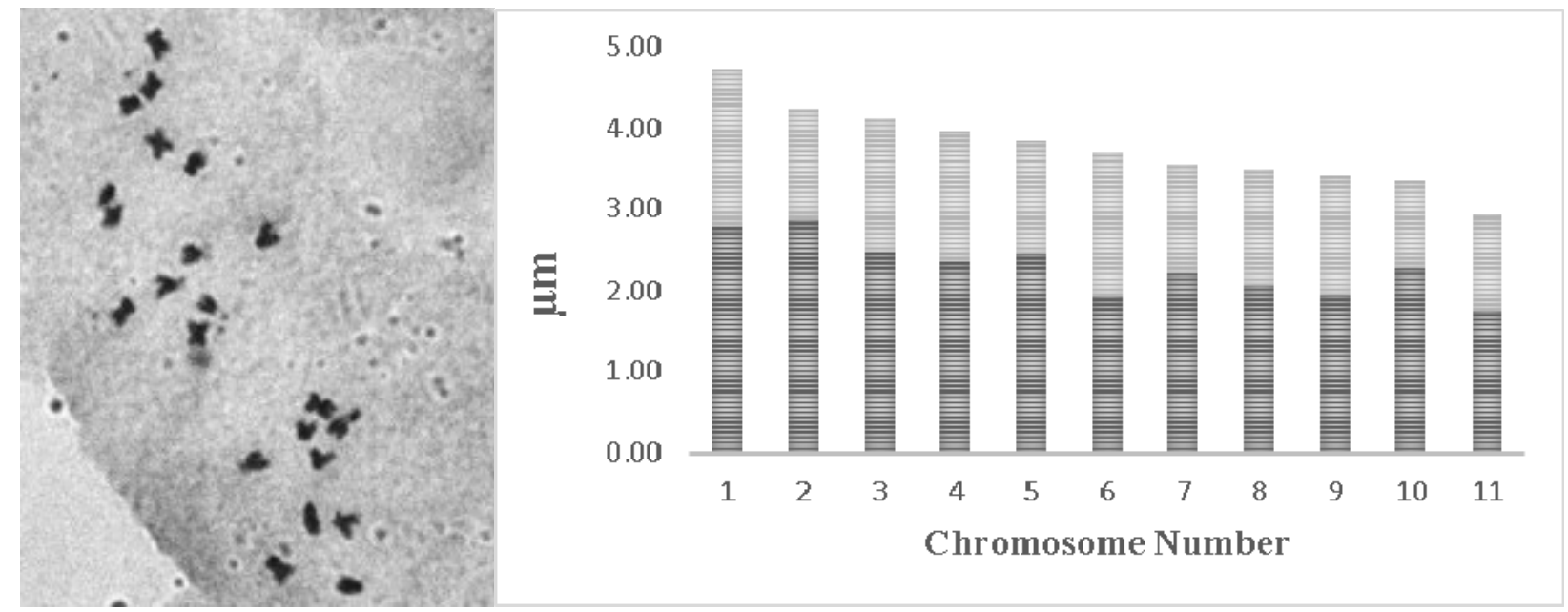

Fig. 1 Somatic metaphases and ideogram of Enton cultivar.

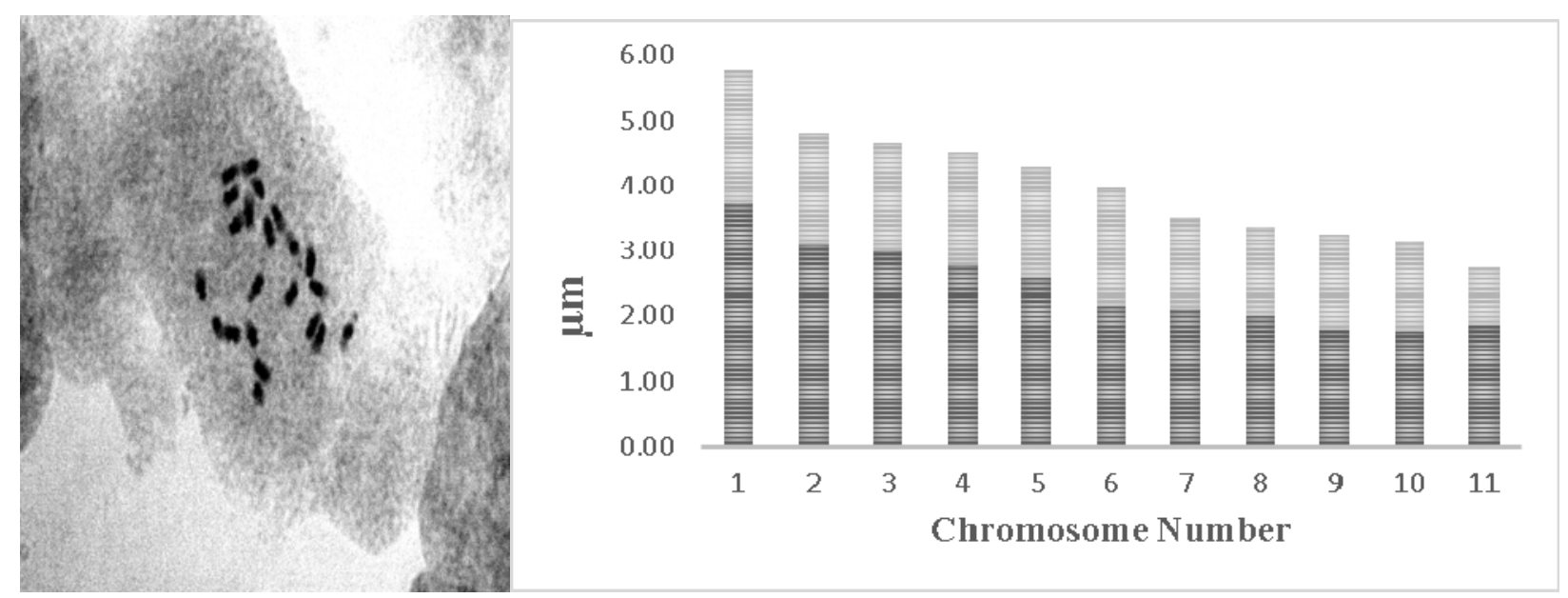

Fig. 2 Somatic metaphases and ideogram of Saglamtimur cultivar.

ideograms were shown in Figs. 1 and 2. The results indicated that the chromosome number of fiddleneck (Phacelia tanacetifolia Benth.) is $2 n=22$. These results are consistent with the results obtained by Sugiura [10] and Cave and Constance [11].

Saglamtimur cultivar has the maximum and minimum values for six parameters. There are the smallest and biggest chromosome length $(2.74 \mu \mathrm{m}$ and $5.79 \mu \mathrm{m}$, respectively), the lowest and highest relative length $(6.23 \%$ and $13.15 \%$, respectively), the maximum long arm length $(3.73 \mu \mathrm{m})$ and the minimum short arm length $(0.89 \mu \mathrm{m})$. Enton cultivar has the smallest and biggest arm ratio (1.08 and 2.50, respectively). In terms of the centromeric index, Enton cultivar has the smallest and biggest centromeric index ( 0.65 and 0.96 , respectively).
The karyotype formulas of the species of fiddleneck (Phacelia tanacetifolia Benth.), on which the karyotype analysis was carried out, were found identical $2 n=22$ ( 16 median +6 submedian).

\subsection{Enton Cultivar}

According to results of Enton cultivar (Table 1), the biggest chromosome length was calculated $4.73 \mu \mathrm{m}$, and the smallest chromosome length was calculated $2.94 \mu \mathrm{m}$. The highest relative length value was measured $11.42 \%$ and the smallest relative value was measured $7.11 \%$. Long arm length was measured between $2.87 \mu \mathrm{m}$ and $1.75 \mu \mathrm{m}$, while short arm length was measured between $1.93 \mu \mathrm{m}$ and $1.10 \mu \mathrm{m}$. Chromosomes arm ratios were calculated between 1.08 and 2.50. The centromeric index was measured 
between 0.96 and 0.64 .

\subsection{Saglamtimur Cultivar}

As a results of Saglamtimur cultivar (Table 1), the largest chromosome length was calculated $5.79 \mu \mathrm{m}$, while the smallest chromosome length was calculated $2.74 \mu \mathrm{m}$. The largest relative length value was measured $13.15 \%$ and the smallest relative value was measured $6.23 \%$. While long arm length was measured between $3.73 \mu \mathrm{m}$ and $1.76 \mu \mathrm{m}$, short arm length was measured between $2.06 \mu \mathrm{m}$ and $0.89 \mu \mathrm{m}$. Chromosomes arm ratios were between 2.08 and 1.16. The centromeric index varies between 0.93 and 0.65 .

\section{Conclusions}

Turkey has the remarkable place for bee culture in the world. The plants like fiddleneck (Phacelia tanacetifolia Benth.), which has better quality, should evaluate more in bee forage for making better situation about bee industry in Turkey. As a result in this research, the varieties of fiddleneck has $2 n=22$ chromosomes and the karyotype formulas is 16 median and 6 submedian, so they can be utilized as parental plant, because of determined chromosome numbers, caryomorphological features and ploidy level. Additionally, this research will make opportunity to investigate the origin of varieties of fiddleneck (Phacelia tanacetifolia Benth.) and then new varieties of fiddlencek are came into use for bee forage farmers in Turkey and the world.

\section{References}

[1] Gilbert, C., Dempcy, J., Ganong, C., Patterson, R., and
Spicer, G. S. 2005. "Phylogenetic Relationships within Phacelia Subgenus Phacelia (Hydrophyllaceae) Inferred from Nuclear rDNA ITS Sequence Data." Systematic Botany 30 (3): 627-34.

[2] Gilbert, L. 2003. What We Know about Its Suitability as an Insectary Plant and Cover in the Mid-Atlantic Region. Small Farm Success Project, Sustainable Agricultural Sysmems Lab., USDA.

[3] Cripps, C., and Rust, R. W. 1988. "Pollen Preferences of Seven Osmia Species (Hymenoptera: Megachilidae).” Environmental Entomology 18 (1): 133-8.

[4] Kumova, U., and Korkmaz, A. 2002. "Importance of Fiddleneck (Phacelia tanacetifolia Benth.) and Researches about Fiddleneck in Turkey." Uludag Arıcıllk Dergisi. 2 (1): 11-6.

[5] Kahl, H. 1996. "Border Strip Planting to Enhance Biological Control of the Cabbage Aphid, Brevicoryne brassicae (L.) by Hoverflies (Diptera: Syrphidae)." Christchurch Polytechnic Institute of Technology, New Zealand. Accesed December 14, 2015. http://www.cpit.ac.nz/hort/res3.htm.

[6] Hickman, J. M., and Wratten, W. D. 1996. "Use of Phacelia tanacetifolia Strips to Enhance Biological Control of Aphids by Hoverfly Larvae in Cereal Fields." Journal of Economic Entomology 89 (4): 832-40.

[7] Serrato-Valenti, G., Mariotti, M. G., Cornara, L., and Corallo, A. 1998. "A Histological and Structural Study of Phacelia tanacetifolia Endosperm in Developing, Mature and Germinating Seed." International Journal of Plant Sciences 159 (5): 753-61.

[8] Reeves, A. 2001. "MicroMeasure: A New Computer Program for the Collection and Analysis of Cytogenetic Data." Genome 44 (3): 439-43.

[9] Levan, A., Fredga, K., and Sandberg, A. A. 1964. "Nomenclature for Centromeric Position on Chromosomes." Hereditas 52 (2): 201-20.

[10] Sugiura, T. 1936. "A List of Chromosome Numbers in Angiospermous Plants II.” Proc. Imp. Acad. 12 (5): 144-6.

[11] Cave, M. S., and Constance, L. 1942. Chromosome Numbers in the Hydrophyllaceae III. Berkeley and Los Angeles: University of California Press, 205-16. 